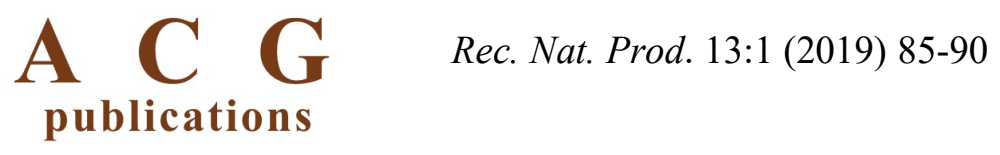

records of natural products

\title{
Chemical Composition and Antihypertensive Effect of Phoenix roebelenii Using Angiotensin Converting Enzyme Inhibition in vitro and in vivo
}

\author{
Karina S. Schumacker ${ }^{1}$, Andrews Marques Nascimento ${ }^{\circledR}$, \\ Anna Paula Rampazzo ${ }^{1}$, Dominik Lenz ${ }^{\circ}$, Helber Barcellos da Costa $\odot^{2}$, \\ Wanderson Romão $\odot^{2,3}$, Rodrigo Scherer ${ }^{1}$, Tadeu Uggere Andrade $\odot^{1 \#}$ and \\ Denise Coutinho Endringer ${ }^{1 * \#}$
}
${ }^{1}$ Program in Pharmaceutical Sciences, University Vila Velha, Vila Velha, ES. CEP 29102-770, Brazil
${ }^{2}$ Petroleomic and Forensic Chemistry Laboratory, Department of Chemistry, Deferal University of Espirito Santo, Vitória, ES. CEP 29075-910, Brazil
${ }^{3}$ Federal Institute of Education, Science and Technology of Espirito Santo, Vila Velha, ES. CEP 29106-010, Brazil

(Received February 26, 2018; Revised May 11, 2018; Accepted May 17, 2018)

\begin{abstract}
This study aimed to evaluate in vivo anti-hypertensive effect of Phoenix roebelenii. To access the chemical composition, the EtOH extract and $\mathrm{CH}_{2} \mathrm{Cl}_{2}$ fraction of $P$. roebelenii were analyzed using electrospray ionization (ESI) source combined with the Fourier transform ion cyclotron resonance mass spectrometry (FTICR-MS) technique. The ACE inhibitory effect was evaluated in vivo by Ang I administration. The antihypertensive assay was performed in Spontaneously Hypertensive Rats (SHR) and Wistar rats that were treated with enalapril $(10 \mathrm{mg} / \mathrm{kg}), \mathrm{CH}_{2} \mathrm{Cl}_{2}$ fraction $(80 \mathrm{mg} / \mathrm{kg}$; twice a day) or vehicle for 30 days. ACE activity in vivo was measured by colorimetric assay. ESI(-)FT-ICR mass spectrum for EtOH extract identified the presence of rutin, quercitrin, kaempferol-7-O-glucoside and kaempferol-3-O-rutenoside, and in the $\mathrm{CH}_{2} \mathrm{Cl}_{2}$ fraction, paradol, gingerol, ursolic/betulinic acid and maslinic/corosolic acid. $\mathrm{CH}_{2} \mathrm{Cl}_{2}$ fraction exhibited antihypertensive effect in vivo by reducing blood pressure in the SHR models. It may be concluded that the presence pungent vanilloids compounds in $\mathrm{CH}_{2} \mathrm{Cl}_{2}$ fraction contributed to the $\mathrm{ACE}$ inhibition in vitro and in vivo and that action could be the mechanism of the anti-hypertensive effect, known for its medicinal value.
\end{abstract}

Keywords: Phoenix roebelenii, phoenix palm; angiotensin converting enzyme; gingerol. C 2018 ACG Publications. All rights reserved.

\section{Plant Source}

Phoenix roebelenii O'Brien, Arecaceae, is popularly known as the dwarf palm and phoenix palm, being used in the decoration of vases, parks and gardens [1].

\footnotetext{
* Corresponding author: E-mail: E-mail: denise.endringer@uvv.br, Phone: +55 (27) 3421-2087

\# contributed equally
}

The article was published by ACG Publications 
The plant material was collected in private gardens in the municipality of Vila Velha, Espírito Santo, Brazil, in June 2012. A voucher specimen was prepared and identified by Profa. M.Sc. Solange Z. Schneider, botanic of the herbarium at the University Vila Velha (UVV), where a voucher specimen is deposited under the number UVVES 1809 . The compound leaves were dried $\left(40{ }^{\circ} \mathrm{C}\right)$, and separated in leaflet and petioles. The leaflets were ground.

\section{Previous Studies}

Data on the biological activity of $P$. roebelenii are scarce [2-4], being reported in vitro inhibitory activity of $\alpha$-glucosidase and $\alpha$-amilose [2] and angiotensin converting enzyme (ACE, 79,7 $\pm 7.4 \%)[4,5]$. These data suggest that the assay described by Serra et al. [2] may be a useful instrument for selecting species for testing in vivo, being reasonable to select $P$. roebelenii to evaluate potential the antihypertensive effects. There is no previous works describing the ability of $P$. roebelinii to reduce in vivo blood pressure at experimental models. Therefore, ACE in vitro inhibition is not being confirmed biologically.

\section{Present Study}

Aliquot (240 g) of ground leaflet material were extracted by percolation with $\mathrm{EtOH}$, followed by extract reduction under reduced pressure at $40^{\circ} \mathrm{C}$ until a residue was formed ( $48 \mathrm{~g}$ ). An aliquot of $15 \mathrm{~g}$ was suspended in water and then partitioned with pentane, $\mathrm{CH}_{2} \mathrm{Cl}_{2}, \mathrm{EtOAc}$. The solvents were removed using rotary evaporator to give dark gummy crude extracts of pentane $(1.1 \mathrm{~g}, 7.30 \%)$, $\mathrm{CH}_{2} \mathrm{Cl}_{2}$ fraction $(2.9 \mathrm{~g}, 19.0 \%)$, EtOAc fraction $(0.8 \mathrm{~g}, 5.30 \%)$ and aqueous fraction $(6.4 \mathrm{~g}, 42.67 \%)$.

Total polyphenol content of the EtOH extract and $\mathrm{CH}_{2} \mathrm{Cl}_{2}$ fraction was quantificated by colorimetric Folin-Ciocalteu method [6]. The analytical curve $\left(y=1.1429 \mathrm{x}+0.007, \mathrm{r}^{2}=0.9977\right)$ was obtained with a solution by pyrogallol (Sigma-Aldrich, St. Louis, USA) $(10-350 \mathrm{mg} / \mathrm{mL})$. The results were expressed as $\mathrm{mg}$ of pyrogallol equivalents $(\mathrm{PE})$ per $\mathrm{g}$ of dry extract. All analyzes were performed in triplicate. As expected, the EtOH extract showed higher content of total polyphenols $(72.3 \pm 5.6 \mathrm{mg}$ $\mathrm{EP} / \mathrm{g}$ of dry extract) $(\mathrm{p}<0.01)$ than the $\mathrm{CH}_{2} \mathrm{Cl}_{2}$ fraction $(27.3 \pm 2.0 \mathrm{mg} \mathrm{EP} / \mathrm{g}$ fraction dry), and higher of previous study [3].

Colorimetric method of aluminum chloride [7] was applied to determine the total amount of flavonoid. The analytical curve $\left(y=0.0033 x+0.0121, r^{2}=0.9991\right)$ was achieved using quercetin solutions (Sigma-Aldrich, St. Louis, USA) (3.91 to $500.00 \mu \mathrm{g} / \mathrm{mL}$ ). The quantification of flavonoid was determined using the analytical curve. The results were expressed as $\mathrm{mg}$ of quercetin equivalents (eq) per g of dry extract. The content of total flavonoid for the EtOH extract $(41.3 \pm 2.0 \mathrm{mg} \mathrm{EQ} / \mathrm{g}$ dry extract) suggested a higher concentration of these constituents.

The EtOH extract and the $\mathrm{CH}_{2} \mathrm{Cl}_{2}$ fraction were diluted to $\approx 0.25 \mathrm{mg} / \mathrm{mL}$ in water: acetonitrile (1:1) which contained $0.1 \% \mathrm{~m} / \mathrm{v}$ of $\mathrm{NH}_{4} \mathrm{OH}$ for ESI in negative mode, ESI(-) and ESI(-)FT-ICR method was performed as previous described $[8,9]$. The mass spectra were acquired and processed using Data Analysis Software (Bruker Daltonics, Bremen, Germany). The MS data were processed, and the elemental compositions of the compounds were determined by measuring the $\mathrm{m} / \mathrm{z}$ values. The proposed structures for each formula were assigned using the chemspider database (www.chemspider.com).

ESI(-)FT-ICR mass spectrum for EtOH extract (Tabel 1) identified mainly the presence of flavonoids (rutin, quercitrin, kaempferol-7-O-glucoside and kaempferol-3-O-rutenoside), in which, their chemical structure, molecular formula, measured and theoretical $\mathrm{m} / \mathrm{z}$ values, mass error and DBE are shown in Table 1. 
Table 1. Chemical composition assigned to signals detected in the ESI(-)FT-ICR mass spectrum of ethanolic extract from leaves of P. roebelenii

\begin{tabular}{|c|c|c|c|c|c|c|c|}
\hline & $m / z_{\text {Measured }}$ & $m / z_{\text {Theoretical }}$ & {$[\mathrm{M}-\mathrm{H}]^{-}$} & $\begin{array}{l}\text { Error } \\
(\mathrm{ppm})\end{array}$ & DBE & Proposed compound & Reference \\
\hline 1 & 255.23303 & 255.23295 & {$\left[\mathrm{C}_{16} \mathrm{H}_{32} \mathrm{O}_{2}-\mathrm{H}\right]^{-}$} & 0.31 & 1 & Palmitic acid & {$[10]$} \\
\hline 2 & 277.18103 & 277.18092 & {$\left[\mathrm{C}_{17} \mathrm{H}_{26} \mathrm{O}_{3}-\mathrm{H}\right]$} & 0.40 & 5 & p-decyloxybenzoic acid & \\
\hline 3 & 335.07745 & 335.0772 & {$\left[\mathrm{C}_{16} \mathrm{H}_{16} \mathrm{O}_{8}-\mathrm{H}\right]^{-}$} & 0.63 & 9 & 5-O-Caffeoylshikimic acid & {$[3,11]$} \\
\hline 4 & 431.09869 & 431.09837 & {$\left[\mathrm{C}_{21} \mathrm{H}_{20} \mathrm{O}_{10}-\mathrm{H}\right]^{-}$} & 0.74 & 12 & Apigetrin & {$[12]$} \\
\hline 5 & 447.09362 & 447.09329 & {$\left[\mathrm{C}_{21} \mathrm{H}_{20} \mathrm{O}_{11}-\mathrm{H}\right]$} & 0.74 & 12 & Quercitrin & {$[12,13]$} \\
\hline 6 & 471.3483 & 471.34798 & {$\left[\mathrm{C}_{30} \mathrm{H}_{48} \mathrm{O}_{4}-\mathrm{H}\right]$} & 0.59 & 7 & $\begin{array}{l}\text { Maslinic acid; } \\
\text { Hederagenin }\end{array}$ & \\
\hline 7 & 593.15157 & 593.15119 & {$\left[\mathrm{C}_{27} \mathrm{H}_{30} \mathrm{O}_{15}-\mathrm{H}\right]$} & 0.64 & 13 & Vicenin-2 & [14] \\
\hline 8 & 609.1467 & 609.14611 & {$\left[\mathrm{C}_{27} \mathrm{H}_{30} \mathrm{O}_{16}-\mathrm{H}\right]^{-}$} & 1.03 & 13 & Rutin & {$[13,15]$} \\
\hline
\end{tabular}

For $\mathrm{CH}_{2} \mathrm{Cl}_{2}$ fraction, the ESI(-)FT-ICR mass spectrum (Table 2) showed the presence of paradol, gingerol, ursolic acid (or betulinic acid) and maslinic acid (or corosolic acid).

Table 2. Chemical composition assigned to signals detected in the ESI(-)FT-ICR mass spectrum of dichlorometanic fraction from of leaves of $P$. roebelenii

\begin{tabular}{cccccccc}
\hline & $m / z_{\text {Measured }}$ & $m / z_{\text {Theoretical }}$ & {$[\mathrm{M}-\mathrm{H}]^{-}$} & $\begin{array}{c}\text { Error } \\
(\mathrm{ppm})\end{array}$ & DBE & Proposed compound & Reference \\
\hline 9 & 255.23298 & 255.23295 & {$\left[\mathrm{C}_{16} \mathrm{H}_{32} \mathrm{O}_{3}-\mathrm{H}\right]^{-}$} & 0.12 & 1 & Ac. Palmitic & {$[3,10]$} \\
\hline 10 & 277.18093 & 277.18092 & {$\left[\mathrm{C}_{17} \mathrm{H}_{26} \mathrm{O}_{3}-\mathrm{H}\right]^{-}$} & 0.04 & 5 & $\begin{array}{c}\text { p-decyloxybenzoic } \\
\text { acid }\end{array}$ & \\
\hline 11 & 293.17588 & 293.17583 & {$\left[\mathrm{C}_{17} \mathrm{H}_{26} \mathrm{O}_{4}-\mathrm{H}\right]^{-}$} & 0.17 & 5 & Unidentified & {$[13]$} \\
\hline 12 & 441,3740 & 441,37480 & {$\left[\mathrm{C}_{30} \mathrm{H}_{50} \mathrm{O}_{2}-\mathrm{H}\right]^{-}$} & -1.79 & 6 & Betulin & {$[13]$} \\
\hline 13 & 455,3533 & 455,3531 & {$\left[\mathrm{C}_{30} \mathrm{H}_{48} \mathrm{O}_{3}-\mathrm{H}\right]^{-}$} & 0.51 & 7 & Betulinic acid & $\begin{array}{c}\text { Maslinic acid; } \\
\text { Hederagenin }\end{array}$ \\
\hline 14 & 471,3482 & 471.34798 & {$\left[\mathrm{C}_{30} \mathrm{H}_{48} \mathrm{O}_{4}-\mathrm{H}\right]^{-}$} & 0.47 & 7 & & \\
\hline
\end{tabular}

The determination of the antioxidant $\mathrm{CH}_{2} \mathrm{Cl}_{2}$ fraction was performed by the method of capturing radicals 2,2-diphenyl-1-picryl hydrazyl (DPPH), as previously described [16]. The percentage of inhibition of DPPH was calculated from the equation: $\mathrm{I} \%=[(\mathrm{Abs} 0-\mathrm{Abs} 1) / \mathrm{Abs} 0] \mathrm{x}$ 100. With the absorbance obtained Abs 0 white and Abs1 the sample absorbance. Increasing concentrations of the sample $(0.2$ to $0.8 \mathrm{mg} / \mathrm{mL})$ were used. The reading was performed in a spectrophotometer at a wavelength of $517 \mathrm{~nm}$. The concentration needed to provide $50 \%$ inhibition of the radical $\left(\mathrm{IC}_{50}\right)$ was calculated by the equation of the straight-line calibration curve $(\mathrm{y}=3.426 \mathrm{x}-$ $\left.0.5071, \mathrm{r}^{2}=0.9924\right)$. The antioxidant was expressed by the degree of antioxidant activity (IAA), which was calculated from the equation: IAA = final concentration of $\mathrm{DPPH} / \mathrm{IC}_{50}$, and $\mathrm{IAA}<0.5$ low antioxidant effect and IAA 0.5, 1.0 antioxidant effect moderate (IAA) between 1.0 and 2.0 strong antioxidant effect and IAA $>2.0$ very strong antioxidant effect [17]. Analyses were performed in triplicate. The $\mathrm{CH}_{2} \mathrm{Cl}_{2}$ fraction showed a marked antioxidant activity $\left(\mathrm{AAI}=2.21\right.$ and $\mathrm{IC}_{50}=18.9$ $\mu \mathrm{g} / \mathrm{mL})$.

The inhibitory activity of extracts and fractions of $P$. roebelenii on ACE were evaluated through cleavage of the substrate Hip-Gly-Gly ECA as described by Endringer et. al. [18]. All samples from $P$. roebelenii inhibited ACE in vitro: leaflet $\mathrm{EtOH}$ extract $(80.2 \pm 13.8 \%)$, leaflet aqueous fraction $(56.0 \pm 2.3 \%)$, leaflet $\mathrm{CH}_{2} \mathrm{Cl}_{2}$ fraction $(88.2 \pm 18.3 \%)$, pentane fraction $(33.33 \pm 2.4 \%)$ and EtOAc fraction $(26.11 \pm 0.8 \%)$. However, the values considered promising for evaluation of in vivo activity, were only that ones with mean inhibition greater than $80 \%$ [18]. Therefore, the $\mathrm{CH}_{2} \mathrm{Cl}_{2}$ fraction was selected for in vivo evaluation.

The in vivo antihypertensive evaluation followed the ethics national and international recommendations for animal experiments and approved by the Ethics Committee, Bioethics and Welfare Animal the UVV (CEUA - UVV; protocol 120/2010). We used spontaneously hypertensive 
rats (SHR) and their normotensive controls, Wistar-Kyoto (WKY). The animals were about three months old, weighing between 280-350 g. SHR and WKY rats were randomly divided into four groups $\left(\mathrm{n}=5\right.$ each). The animals received a daily treatment of $\mathrm{CH}_{2} \mathrm{Cl}_{2}$ fraction (SHRP and WKYP) solution. The animals in the control groups (SHR and WKY) received the vehicle (sunflower oil). The treatment was performed for 30 days using a dose of $40 \mathrm{mg} / \mathrm{kg} \mathrm{CH}_{2} \mathrm{Cl}_{2}$ fraction solution twice a day intraperitoneally with a 12 hours interval between them $(80 \mathrm{mg} / \mathrm{kg} /$ day $)$. The animals were kept in a vivarium of UVV, at a temperature of $22 \pm 3^{\circ} \mathrm{C}$, in a cycle of $12 \mathrm{~h}$ light $/ 12 \mathrm{~h}$ dark with free access to standard pellet diet (diet Probiotério, Mill Primor SA) and tap water.

The animals submitted to chronic anti-hypertensive treatment were weighed at the beginning of the experiment (initial body weight - IBW) and distributed according to the body weight evenly between the various groups: SHRP, WKYP, SHR and WKY in individual cages. The animals were weighed daily to calculate the dose (volume) of the solution being administered. On the day of the experimental protocol animals were weighed for the last time, obtaining the final body weight $(\mathrm{CCW})$ of these animals.

At the end of the experimental protocol, the animals submitted to chronic anti-hypertensive treatment were euthanized by decapitation. The hearts were removed to obtain the estimated weight and cardiac hypertrophy. They were isolated, washed with saline solution and excess liquid was removed with filter paper and then weighed. The ratio of heart weight $(\mathrm{mg})$ final body weight $(\mathrm{g})$ (HEART / BW) was used as an index of cardiac hypertrophy. In the antihypertensive evaluation, the administration of $\mathrm{CH}_{2} \mathrm{Cl}_{2}$ fraction inhibited did not alter MAP in WKY animals (Table 3), but the treatment decreased MAP in the SHRP group when compared with the SHRP $(p<0.01)$ (Table 3$)$. The MAP reduction after chronic administration of $\mathrm{CH}_{2} \mathrm{Cl}_{2}$ fraction inhibited was similar to those elicit by the enalapril treated SHR (Table 3).

The $\mathrm{CH}_{2} \mathrm{Cl}_{2}$ fraction did not change the HEART/BW in WKY animals (Table 3). However, in the SHR, the treatment with $\mathrm{CH}_{2} \mathrm{Cl}_{2}$ fraction reduced this ratio $(\mathrm{p}<0.01)$ with the same magnitude of the SHRE group. However, these parameters (MAP and HEART/BW) were not normalized by treatment with $\mathrm{CH}_{2} \mathrm{Cl}_{2}$ fraction, where as they maintained higher as compared with the groups of WKY animals $(\mathrm{p}<0.01)($ Table 3$)$.

ACE activity was lower in the serum of SHR treated groups $(\mathrm{SHRP}=45.0 \pm 5.0 \%$, SHRE $=$ $46.4 \pm 3.0 \%)$ compared with negative SHR control group $(82.0 \pm 8.0 \%)(\mathrm{p}<0.05)$. The same was observed in the WKY treated groups (WKYP $=54.0 \pm 4.0 \%$, WKYE $=47.8 \pm 4.0 \%)$ in relation with the negative WKY control animal $(64.0 \pm 4.0 \%)(\mathrm{p}<0.05)$. No difference was observed between the SHR treated with the normotensive animals.

Table 3. Hemodynamic parameters, heart weight to body weight ratio (HW/BW) of the experimental groups

\begin{tabular}{cccc}
\hline Group & MAP $(\mathbf{m m H g})$ & HR $(\mathbf{b p m})$ & HEARTH/BW $(\mathbf{m g} / \mathbf{g})$ \\
\hline WKY & $109 \pm 5$ & $315 \pm 10$ & $2.71 \pm 0.08$ \\
WKYP & $108 \pm 4$ & $322 \pm 11$ & $2.69 \pm 0.10$ \\
WKYE & $109 \pm 2$ & $291 \pm 26$ & $2.789 \pm 0.22$ \\
SHR & $184 \pm 8^{* *}$ & $333 \pm 14$ & $3.53 \pm 0.02^{* *}$ \\
SHRE & $152 \pm 4^{* * \# \#}$ & $309 \pm 20$ & $3.24 \pm 0.19^{* * \#}$ \\
SHRP & $146 \pm 9^{* * \# \#}$ & $338 \pm 12$ & $3.28 \pm 0.03^{* * \# \#}$
\end{tabular}

WKY $=$ Wistar Kyoto animals with no treatment; WKYP $=$ Wistar Kyoto animals treated with dichloromethane fraction extract of $P$. roebelenii (DOSE); SHR = Spontaneously Hypertensive Rats with no treatment; SHRP = Spontaneously Hypertensive Rats treated with dichloromethane fraction extract of P. roebelenii . WKYE $=$ Wistar Kyoto animals treated with enalapril $\left(10 \mathrm{mg} \cdot \mathrm{kg}^{-1}\right)$; $\mathrm{SHR}=$ Spontaneously Hypertensive Rats treated with enalapril $\left(10 \mathrm{mg} \cdot \mathrm{kg}^{-1}\right)$. Values are expressed as mean \pm S.E.M. ${ }^{* *} \mathrm{p}<0.05$ compared with normotensive animals. ${ }^{\#} \mathrm{p}<0.05$ compared to animals SHR group. MAP = Mean arterial pressure; HR= Heart rate.

There was an increase in the final body weight in WKY (IBW: $243 \pm 47 \mathrm{~g}$ vs. FBW: $316 \pm$ 51g; $p<0.05$ ), WKYP (IBW: $245 \pm 38 \mathrm{~g}$ vs. FBW: $304 \pm 22 \mathrm{~g}$; $\mathrm{p}<0.05$ ) and WKYE (IBW: $247 \pm 44 \mathrm{~g}$ vs. FBW: $301 \pm 13 \mathrm{~g} ; \mathrm{p}<0.05)$ compared with its respective initial body weight. In the hypertensive groups 
experimental groups there was no change in the FBW (SHR: $288 \pm 13$; SHRP: $287 \pm 14$; SHRE: $285 \pm$ 11) compared with the IBW (SHR: $306 \pm 19$; SHRP: $302 \pm 24$; SHRE: $288 \pm 16$ ).

This study showed the antihypertensive effect of $P$. roebelenii in SHR rats. The chemical compounds of $\mathrm{CH}_{2} \mathrm{Cl}_{2}$ fraction (pungent vanilloids and triterpenes compounds) showed effect on the components on the renin-angiotensin system (RAS).

Altogether, these results indicate that $\mathrm{CH}_{2} \mathrm{Cl}_{2}$ fraction from the EtOH extract $P$. roebelenii has a marked concentration of gingerol-type compounds and significantly reduce blood pressure on the SHR model. One of the mechanisms of the antihypertensive effect is related to inhibition of ACE, since the dichloromethane fraction inhibit this enzyme in vitro and in vivo. These data suggest the potential anti-hypertensive activity of $\mathrm{CH}_{2} \mathrm{Cl}_{2}$ fraction of $P$. roebelenii.

\section{Acknowledgments}

FAPES / Brazil (Fundação de Amparo à Pesquisa do Espírito Santo) is acknowledged for research fellowship (KSS, AMN, TUA and DCE) and also for financial supported this project. Conselho Nacional de Desenvolvimento Científico e Tecnológico $(\mathrm{CNPq})$ for financial support (PQProcesso: 310680/2016-6).

\section{Supporting Information}

Supporting Information accompanies this paper on http://www.acgpubs.org/RNP

\section{ORCID}

Karina S. Schumacker: 0000-0002-3774-1019

Andrews Marques Nascimento: 0000-0002-9906-3874

Anna Paula Rampazzo: 0000-0002-2496-3595

Dominik Lenz: 0000-0001-6932-401X

Helber Barcellos da Costa: 0000-0001-9175-370X

Wanderson Romão: 0000-0002-2254-6683

Rodrigo Scherer: 0000-0001-7656-0248

Tadeu Uggere de Andrade: 0000-0001-6387-7895

Denise Coutinho Endringer: 0000-0001-9396-2097

\section{References}

[1] P. Idárraga, and P. Callejas (2011). Análisis florístico de la vegetación del Departamento de Antioquia. Flora de Antioquia: Catálogo de las plantas vasculares, 2, 7-115.

[2] A. Roy and G. Mahalingam (2017). The in-vitro antidiabetic activity of Phoenix roenelenii extract, I.J.G.P. 11(1), S128-S134.

[3] A.N. Singab, E.M.M. El-Taher, M.R. Elgindi and M.E.S. Kassem (2015). Phoenix roebelenii O'Brien DNA profiling, bioactive constituents, antioxidant and hepatoprotective activities, Asian Pac. J. Trop. Dis. 5(7), 552-558.

[4] C.P. Serra, S. F. Côrtes, J.A. Lombardi, A.B. De Oliveira, and F.C. Braga (2005). Validation of a colorimetric assay for the in vitro screening of inhibitors of angiotensin-converting enzyme (ACE) from plant extracts, Phytomedicine 12(6), 424-432.

[5] F.C. Braga, C.P. Serra, N.S. Viana Júnior, A.B. Oliveira, S.F. Côrtes and J.A. Lombardi (2007). Angiotensin-converting enzyme inhibition by Brazilian Plant, Fitoterapia 78, 353-358.

[6] V. L. Singleton, R. Orthofer, and R.M. Lamuela-Raventós (1999). Analysis of total phenols and other oxidation substrates and antioxidants by means of folin-ciocalteu reagent, Met.enzymol. 299, 152-178.

[7] S. F. AbouZid, and G.M.Elsherbeiny (2013). Increase in flavonoids content in red onion peel by mechanical shredding, J. Med. Plants Res. 2(9), 258-260.

[8] F.P.S. Ferreira, S.R. Morais, M.T.F. Bara, E.C. Conceição, J.R. Paula, T.C. Carvalho, B.G. Vaz, H.B. Costa, W. Romão and M.H. Rezende (2014). Eugenia calycina Cambess extracts and their fractions: 
Their antimicrobial activity and the identification of major polar compounds using electrospray ionization FT-ICR mass spectrometry, J. Pharm. Biomed. Anal. 99, 89-96.

[9] J.C.B. Carvalho, K.C.I. Sousa, D.C. Brito, A.A. Chaibub, A.P. Luzini, M.V.C.B. Côrtes, M.C.C. Filippi, L. Kato, B.G. Vaz, H.B. Costa, W. Romão and L.G. Araújo (2015). Biocontrol potential of Waitea circinata, an orchid mycorrhizal fungus, against the rice blast fungus, Trop. Plant. Pathol. 40(3), 151159.

[10] E.d.T. Bouhlali, C. Alem, J.Ennassir, M. Benlyas, A.N. Mbark and Y. F. Zegzouti (2017). Phytochemical compositions and antioxidant capacity of three date (Phoenix dactylifera L.) seeds varieties grown in the South East Morocco, J. Saudi Soc. Agricult. Sci. 16, 350-357.

[11] J. B. Harborne, C. A.Williams, J.Greenham and P. Moyna (1974). Distribution of charged flavones and caffeylshikimic acid in Palmae, Phytochemistry 13, 1557-1559.

[12] J. K. Prasain,C.-C. Wang, and S. Barnes (2004). Mass spectrometric methods for the determination of flavonoids in biological samples, Free Radical Bio. Med. 37, 1324-1350.

[13] H.H. F. Koolen, E.R. Soares, F.M.A. Silva, A.Q.L. Souza, E. Rodrigues Filho and A.D. Souza (2012). Triterpenes and flavonoids from the roots of Mauritia flexuos, Rev. Bras. Farmacogn. 22(1), 189-192.

[14] D.B. Silva, I.C.C Turatti, D.R. Gouveia, M. Ernst, S.P. Teixeira and N.P. Lopes (2014). Mass spectrometry of flavonoid vicenin-2, based sunlight barriers in Lychnophora species, Sci. Rep. 4, 1-8.

[15] F. Cuyckens and M. Claeys (2004). Mass spectrometry in the structural analysis of flavonoids, J. Mass Spectrom. 39, 1-15.

[16] W. Brand-Williams, M.-E. Cuvelier, and C. Berset. (1995). Use of a free radical method to evaluate antioxidant activity, LWT-Food Sci. Technol. 28(1), 25-30

[17] R. Scherer and H.T. Godoy (2009). Antioxidant activity index (AAI) by the 2, 2-diphenyl-1picrylhydrazyl method, Food chem. 112(3), 654-658

[18] D.C. Endringer, O.V. Oliveira, and F.C. Braga (2014). In vitro and in silico inhibition of angiotensinconverting enzyme by carbohydrates and cyclitols, Chem. Paper 68(1), 37-45

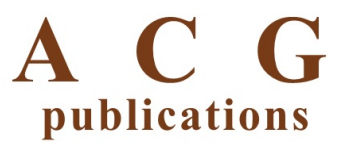

(C) 2018 ACG Publications 